\title{
Growth, nutrient accumulation in leaves and grain yield of super early genotypes of common bean ${ }^{1}$
}

\author{
Adriano Stephan Nascente ${ }^{2}$, Maria da Conceição Santana Carvalho², Paulo Holanda Rosa ${ }^{3}$
}

\section{ABSTRACT}

There is a lack of researches that evaluate the development and nutrient accumulation in super early genotypes of common bean for the elaboration of fertilization programs. This study aimed at characterizing the development; N, P, K, Ca and $\mathrm{Mg}$ accumulation by leaves; grain yield; and yield components of super early genotypes of common bean. Field experiments were conducted in a randomized blocks design, with four replications. The treatments consisted of the IPR Colibri (control), CNFC 15873, CNFC 15874 and CNFC 15875 genotypes. Plants were sampled throughout the common bean development, being divided into leaves, stems and pods. After determining the dry matter, the contents of N, P, K, Ca and $\mathrm{Mg}$ accumulated in leaves were estimated. At harvesting, the grain yield and yield components were evaluated. The biomass accumulation in stems and leaves occurred until the flowering stage, and then it started in the pods until harvesting. The genotypes that absorbed more nitrogen and phosphorus had a higher grain yield. The average growing season of super early genotypes was 70 days (winter) and 63 days (summer). CNFC 15874 was the most productive genotype in the winter, with grain yield similar to the IPR Colibri cultivar (control). In the summer, CNFC 15873 and CNFC 15875 achieved grain yield similar to the IPR Colibri cultivar.

KEY-WORDS: Phaseolus vulgaris; Brazilian Savannah; sustainable agriculture.

\section{INTRODUCTION}

The common bean crop has a significant economic importance in many countries, and is considered an essential source of proteins for human consumption. However, despite its importance, technologies such as new varieties, fertilization and control of insects, diseases and weeds are seldom used by common bean farmers, resulting in a global average grain yield of only $804 \mathrm{~kg} \mathrm{ha}^{-1}$ (FAO 2016).

\section{RESUMO}

Crescimento, acúmulo de nutrientes nas folhas e produtividade de grãos de genótipos superprecoces de feijoeiro comum

Há carência de estudos que avaliem o desenvolvimento e o acúmulo de nutrientes em genótipos superprecoces de feijoeiro comum, para a elaboração de programas de fertilização. Objetivouse caracterizar o desenvolvimento, acúmulo de $\mathrm{N}, \mathrm{P}, \mathrm{K}, \mathrm{Ca}$ e $\mathrm{Mg}$ nas folhas, produtividade de grãos e componentes de produção de genótipos superprecoces de feijoeiro comum. Experimentos de campo foram realizados em delineamento de blocos ao acaso, com quatro repetições. Os tratamentos consistiram dos genótipos IPR Colibri (controle), CNFC 15873, CNFC 15874 e CNFC 15875. Foram amostradas plantas durante o desenvolvimento do feijoeiro, com separação em folhas, hastes e vagens. Após a determinação da matéria seca, foi analisado o conteúdo de N, P, K, Ca e Mg nas folhas. Na colheita, foram avaliados os componentes de produção e produtividade de grãos. O acúmulo de biomassa nos caules e folhas ocorreu até a floração, e depois começou nas vagens até a colheita. Os genótipos que absorveram mais nitrogênio e fósforo tiveram maior produtividade de grãos. A média do ciclo dos genótipos foi de 70 dias (inverno)e 63 dias (verão). CNFC 15874 foi a linhagem mais produtiva na safra de inverno, com produtividade semelhante à da IPR Colibri (controle). Na safra de verão, CNFC 15873 e CNFC 15875 alcançaram produtividades de grãos semelhantes à da cultivar IPR Colibri.

PALAVRAS-CHAVE: Phaseolus vulgaris; Cerrado; agricultura sustentável.

The use of super early genotypes of common bean would allow the achievement of higher grain yields in a shorter time, thus saving irrigation water and overall energy used for production, reducing costs (Nascente et al. 2016). This technology would also allow better land uses, such as the cultivation of two crops during the rainy season, or even up to three crops during the same year, in irrigated areas (Nascente \& Melo 2015).

Due to their short life cycle, the super early genotypes may escape drought even when sowing is

1. Manuscript received in May/2016 and accepted for publication in Sep./2016 (http://dx.doi.org/10.1590/1983-40632016v4641144).

2. Empresa Brasileira de Pesquisa Agropecuária (Embrapa Arroz e Feijão), Santo Antônio de Goiás, GO, Brazil.

E-mails: adriano.nascente@embrapa.br, maria.carvalho@embrapa.br.

3. Uni-Anhanguera, Goiânia, GO, Brazil.E-mail: paulonky@hotmail.com. 
performed late in the rainy season. In addition, the use of super early genotypes would reduce costs and production risks, since cultivars with shorter cycles provide the most rapid removal of crops from the field. Therefore, it is likely that the crop becomes less subject to attacks of insects and diseases, as well as competition with weeds.

The production of more food in the shortest time is very important for many developing regions, such as the Latin America and Eastern and Southern Africa, which use grains from this crop in their daily human diets (Rosales-Serna et al. 2004, Lima et al. 2005).

The Embrapa Arroz e Feijão has developed new genotypes of common bean with super early cycle. These genotypes have life cycles of 65-75 days, in contrast with the 90-100 days of traditional cultivars. However, these elite lines have to be better characterized, in order to develop a management system that allows the full exploitation of their genetic potential (Nascente \& Melo 2015).

The plant growth analysis and determination of nutrient absorption capacity, during the growing season, may allow the rational use of inputs such as water and nutrients, aiming at its productive potential (Augostinho et al. 2008, Pegoraro et al. 2014). The determination of dry biomass accumulation (plant and its parts: stems, leaves and pods) is the most suitable tool for the growth analysis (Rosales-Serna et al. 2004, Andrade et al. 2009, Santos et al. 2015). It may be used to verify the crop adaptation to new environments, interspecific competition, effects of the management system and yield potential of different genotypes (Antoniazzi \& Deschamps 2006, Falqueto et al. 2009, Alvarez et al. 2012).

The determination of the nutrients absorption capacity of these new genotypes could be an important tool for defining fertilization strategies (Haag et al. 1967), in terms of quantity demanded by the common bean and the most appropriate times to perform the fertilization (Anghinoni 2007). The accumulation of nutrients in these new super early genotypes could be used as a nutrient extraction parameter of the soil for future fertilization recommendation systems (Fageria et al. 2011, Pagani \& Mallarino 2012, Crusciol et al. 2013).

Phases of higher demand and accumulation of nutrients in common bean could be indicated by the absorption of nutrients by leaves (Pergoraro et al. 2014), since this plant structure accumulates nutrients until the flowering stage to be translocated to the pods (Wien et al. 1976).
Vieira et al. (2009) evaluated the accumulation of nutrients and the agronomic performance of common bean cultivars, in different populations and farming systems, and observed a maximum accumulation of nutrients at the end of the crop cycle, with the nutrient content absorbed and transported by the plant in the following order: $\mathrm{N}>\mathrm{K}>\mathrm{Ca}>\mathrm{Mg}>$ P. Pergoraro et al. (2014) found that the absorption of nutrients by the common bean was as it follows: $138 \mathrm{~kg} \mathrm{ha}^{-1}$ of $\mathrm{K}, 112 \mathrm{~kg} \mathrm{ha}^{-1}$ of $\mathrm{N}$, $66 \mathrm{~kg} \mathrm{ha}^{-1}$ of Ca, $16 \mathrm{~kg} \mathrm{ha}^{-1}$ of P, $11 \mathrm{~kg} \mathrm{ha}^{-1}$ of S and $7 \mathrm{~kg} \mathrm{ha}^{-1}$ of $\mathrm{Mg}$.

Thus, this study aimed at characterizing the development; N, P, K, Ca and Mg accumulation by leaves; grain yield; and yield components of super early genotypes of common bean.

\section{MATERIAL AND METHODS}

The field experiments were conducted in two growing seasons (2015 and 2015/2016), at the Capivara Farm $\left(16^{\circ} 28^{\prime} 00^{\prime \prime} \mathrm{S}, 49^{\circ} 17^{\prime} 00^{\prime \prime} \mathrm{W}\right.$ and altitude of $823 \mathrm{~m}$ ), in Santo Antônio de Goiás, Goiás State, Brazil. The climate is tropical Savannah (Aw, according to the Köppen classification), with two well-defined seasons: dry (from May to September - autumn/winter) and rainy (from October to April - spring/summer). The daily average temperature and precipitation during the experiment were monitored (Figure 1).

The soil was classified as a clay loam (kaolinitic, thermic Typic Haplorthox) acidic soil. Prior to each experiment, the soil chemical characteristics were determined (Claessen 1997) (Table 1).

The experimental area had been cultivated under a no-tillage system for seven consecutive years. The last crop rotation consisted of soybean (spring/ summer) followed by maize (Zea mays L. - summer) and common bean (autumn/winter), for the two trials. The maize dry biomass on the soil surface, at the common bean sowing, was $12 \mathrm{Mg} \mathrm{ha}^{-1}$ (2015) and $3 \mathrm{Mg} \mathrm{ha}^{-1}(2015 / 2016)$.

A complete randomized blocks design, with four replicates, in two growing seasons (2015 and 2015/2016), was used. Treatments consisted of common bean genotypes (IPR Colibri - control, CNFC 15873, CNFC 15874 and CNFC 15875).

The IPR Colibri cultivar, which has a reduced life cycle and is commonly used by farmers, was considered a control for comparison with the new 


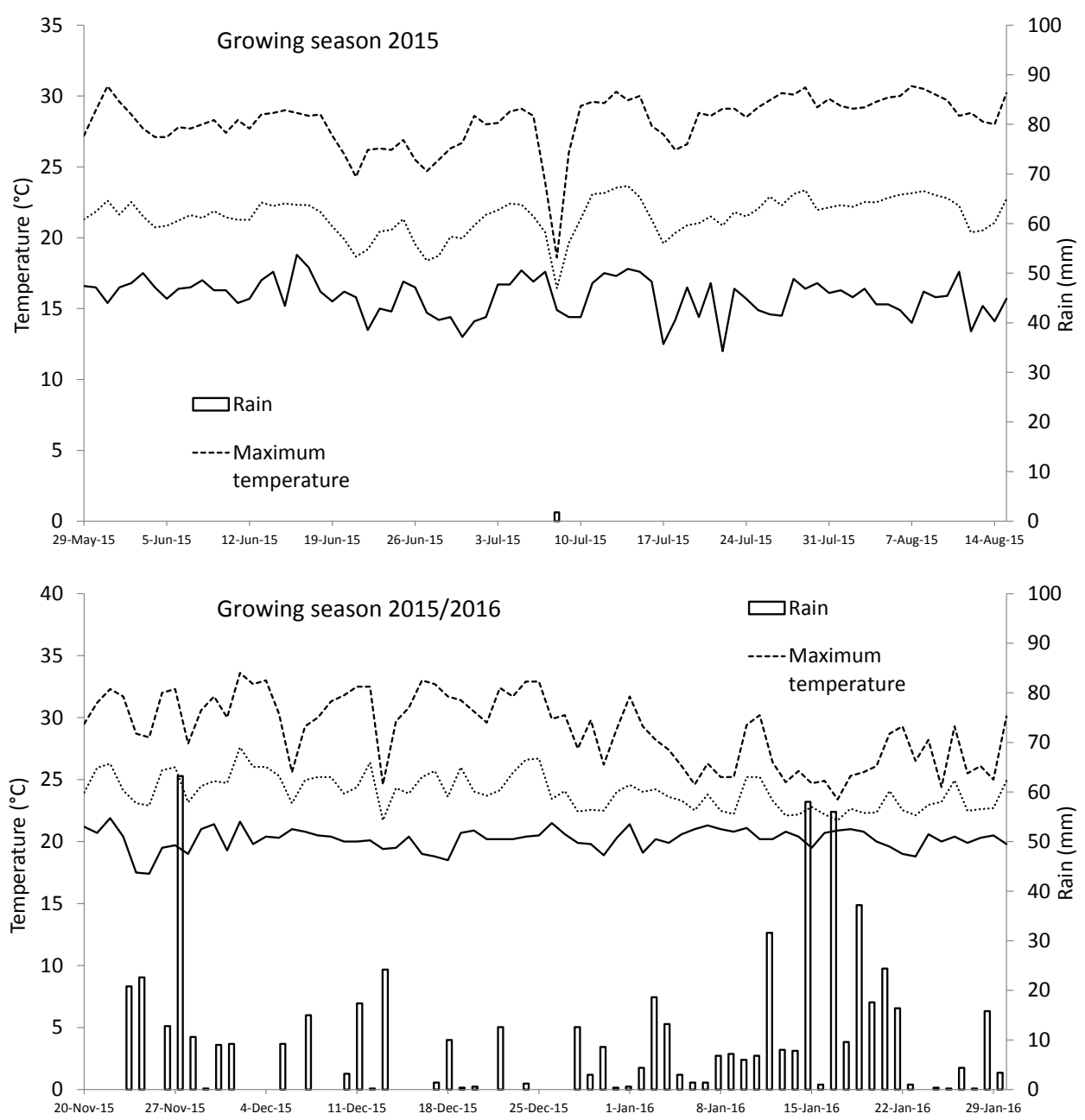

Figure 1. Maximum, minimum and average temperatures and rainfall, in the 2015 and 2015/2016 growing seasons.

Table 1. Chemical soil attributes from the experimental area before the beginning of the trials.

\begin{tabular}{|c|c|c|c|c|c|c|}
\hline \multicolumn{7}{|c|}{2015 growing season } \\
\hline Layer & $\mathrm{pH}$ & $\mathrm{Ca}$ & $\mathrm{Mg}$ & $\mathrm{Al}$ & $\mathrm{H}+\mathrm{Al}$ & Organic matter \\
\hline $\mathrm{cm}$ & $\mathrm{H}_{2} \mathrm{O}$ & \multicolumn{4}{|c|}{$\mathrm{mmol}_{\mathrm{c}} \mathrm{dm}^{-3}$} & $\mathrm{~g} \mathrm{~kg}^{-1}$ \\
\hline $0-5$ & 6.2 & 23.0 & 13.0 & 0.0 & 36.0 & 26.80 \\
\hline $5-10$ & 5.7 & 6.1 & 3.9 & 3.0 & 33.0 & 23.35 \\
\hline $10-20$ & 5.5 & 5.8 & 3.5 & 2.0 & 24.0 & 20.83 \\
\hline Layer & $\mathrm{K}$ & $\mathrm{P}$ & $\mathrm{Cu}$ & $\mathrm{Zn}$ & $\mathrm{Fe}$ & $\mathrm{Mn}$ \\
\hline $\mathrm{cm}$ & $\mathrm{mmol}_{\mathrm{c}} \mathrm{dm}^{-3}$ & & 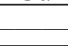 & $\operatorname{lg~dn}$ & & \\
\hline $0-5$ & 3.6 & 22.5 & 1.5 & 4.4 & 38.2 & 9.0 \\
\hline $5-10$ & 1.2 & 38.5 & 1.8 & 2.1 & 37.0 & 3.5 \\
\hline $10-20$ & 1.2 & 13.0 & 1.7 & 1.9 & 27.3 & 3.7 \\
\hline \multicolumn{7}{|c|}{$2015 / 2016$ growing season } \\
\hline Layer & $\mathrm{pH}$ & $\mathrm{Ca}$ & $\mathrm{Mg}$ & $\mathrm{Al}$ & $\mathrm{H}+\mathrm{Al}$ & Organic matter \\
\hline $\mathrm{cm}$ & $\mathrm{H}_{2} \mathrm{O}$ & \multicolumn{4}{|c|}{$\mathrm{mmol}_{\mathrm{c}} \mathrm{dm}^{-3}$} & $\mathrm{~g} \mathrm{~kg}^{-1}$ \\
\hline $0-5$ & 6.5 & 70.0 & 22.0 & 0.0 & 18.0 & 45.74 \\
\hline $5-10$ & 6.6 & 77.0 & 22.0 & 0.0 & 15.0 & 41.17 \\
\hline $10-20$ & 6.1 & 59.0 & 18.0 & 0.0 & 13.0 & 40.93 \\
\hline Layer & $\mathrm{K}$ & $\mathrm{P}$ & $\mathrm{Cu}$ & $\mathrm{Zn}$ & $\mathrm{Fe}$ & $\mathrm{Mn}$ \\
\hline $\mathrm{cm}$ & $\mathrm{mmol}_{\mathrm{c}} \mathrm{dm}^{-3}$ & \multicolumn{4}{|c|}{$\mathrm{mg} \mathrm{dm}{ }^{-3}$} & \\
\hline $0-5$ & 8.8 & 17.7 & 0.7 & 4.1 & 9.0 & 50.80 \\
\hline $5-10$ & 5.6 & 17.3 & 0.7 & 3.6 & 7.0 & 40.40 \\
\hline $10-20$ & 3.4 & 6.3 & 0.7 & 2.7 & 7.7 & 30.80 \\
\hline
\end{tabular}


super early genotypes. The plots consisted of ten $8 \mathrm{~m}$ long rows. The useful area of each plot was formed by the six central meters of the four central rows.

Approximately 15 days before sowing, the experimental area was desiccated with glyphosate + 2.4D. The base fertilization, applied in the sowing furrows, was calculated according to Sousa \& Lobato (2004). The fertilizer applied at sowing consisted of $105 \mathrm{~kg} \mathrm{ha}^{-1}$ of $\mathrm{P}_{2} \mathrm{O}_{5}$ (triple superphosphate) and $52.5 \mathrm{~kg} \mathrm{ha}^{-1}$ of $\mathrm{K}_{2} \mathrm{O}$ (potassium chloride). Nitrogen fertilization was carried out at the V4 stage (fourth trifoliate unfolded), using $90 \mathrm{~kg} \mathrm{ha}^{-1}$ of $\mathrm{N}$ as urea.

The common bean genotypes were sown mechanically (Semeato, model Personale Drill 13, Passo Fundo, RS, Brazil) on May 29 and November 20, in 2015 , in a $0.45 \mathrm{~m}$ row spacing, with 15 seeds $\mathrm{m}^{-1}$. Cultural practices were performed according to recommendations for the crop, in order to keep the area free of weeds, diseases and insects. In the 2015 growing season (dry season), a central pivot irrigation system was used. The water management followed the methods recommended by Doorenbos \& Pruitt (1976).

Seedling emergence occurred at eight (2015) and five (2015/2016) days after sowing. The averages for the V4 stage were observed at 15 and 12 days after emergence (DAE) and for the full flowering stage at 39 and 36 DAE, respectively in the 2015 and $2015 / 2016$ growing seasons. The average growing season (length of time from emergence to harvest) was 70 days (August 15, 2015) and 63 days (January 27, 2016).

Samples were collected at 21, 28, 35, 42, 49, 56 and 63 DAE and 12, 19, 40, 56 and 63 DAE, respectively for the 2015 and $2015 / 2016$ growing seasons. In each experimental unit, plants inside a $1.0 \mathrm{~m}$ row were collected and then divided into leaves, stems and pods, while the roots were discarded. These plant structures were dried at $60^{\circ} \mathrm{C}$, in an oven with forced air circulation, until constant mass. The dry biomass production of each plant structure was calculated, as well as total biomass (leaves + stems + pods).

After dried, the leaves were ground and analyzed for chemical composition. The concentrations of $\mathrm{N}$, $\mathrm{P}, \mathrm{K}, \mathrm{Ca}$ and $\mathrm{Mg}$ were determined according to Malavolta et al. (1997). Nitrogen was extracted with $\mathrm{H}_{2} \mathrm{SO}_{4}$ and the other nutrients with a nitro-perchloric solution. The $\mathrm{N}$ concentration in the digested solution was determined by Kjeldahl analysis. The P, K, Ca and $\mathrm{Mg}$ concentrations were determined by atomic absorption spectrophotometry. The content of each nutrient was calculated by multiplying the biomass production of leaves by the concentration of this nutrient.

The common bean seeds harvested were weighed and the yield expressed in $\mathrm{kg} \mathrm{ha}^{-1}$, with water content of $130 \mathrm{~g} \mathrm{~kg}^{-1}$ in the grains. In addition, the following yield components were assessed: number of pods per plant, number of seeds per pod (evaluated in 10 plants per plot, that were chosen at random) and weight of 100 seeds (calculated from eight random samples per plot).

Grain yield and yield components were evaluated at harvesting in the 2015 and 2015/2016 growing seasons. Then, an analysis of variance and $F$ test were performed for all variables. The analysis of variance was performed considering the effects of genotypes. For the significant data, the LSD test $(p<0.05)$ was performed. These analyses were carried out using the SAS statistical software. Data of common bean biomass accumulation and nutrient accumulation in leaves, during the common bean life cycle, were subjected to a process of curve fitting to a polynomial model. In addition, a Person's correlation of nutrients accumulation in common bean leaves was performed with number of pods per plant, number of grains per pod, mass of 100 grains and grain yield.

\section{RESULTS AND DISCUSSION}

Regarding the growth analysis, it was found that the data of leaf and stem biomass fitted quadratic models (Figures 2 and 3 ). Therefore, at the early stage of plant development, the accumulation of stem and leaf biomass occurred just until after flowering, when the production of pods and grains began, at $42 \mathrm{DAE}$ and 40 DAE, respectively in the 2015 and 2015/2016 growing seasons (Figure 3). Thus, it seems that, at the flowering stage, the translocation of nutrients from leaves and stems started for the formation of pods and grains.

According to Wien et al. (1976), at pod formation and grain filling, about $45 \%$ of the leaves and stems assimilates are translocated to the seeds. Corroborating this information, all data of the nutrients in the leaves also fitted quadratic equations (Figures 4 and 5). The nutrients in the leaves were accumulated up to 42-49 DAE (Figure 4) and 40 DAE 
(Figure 5), respectively in the 2015 and 2015/2016 growing seasons, when the nutrient content in the leaves began to reduce. This is a clear indication that these nutrients were being translocated to the pods.

The winter growing season has a lower average temperature than the summer one (Figure 1). Thus, the crop cycle in the coldest season is longer, and this was also reflected in the period up to when there was accumulation of nutrients by plants. The nutrient accumulation period was longer in the winter growing season. Besides, in the 2015/2016 growing season, there was a higher production of biomass in all genotypes, when compared to the 2015 growing season (Figure 3). This may be a reflection of the
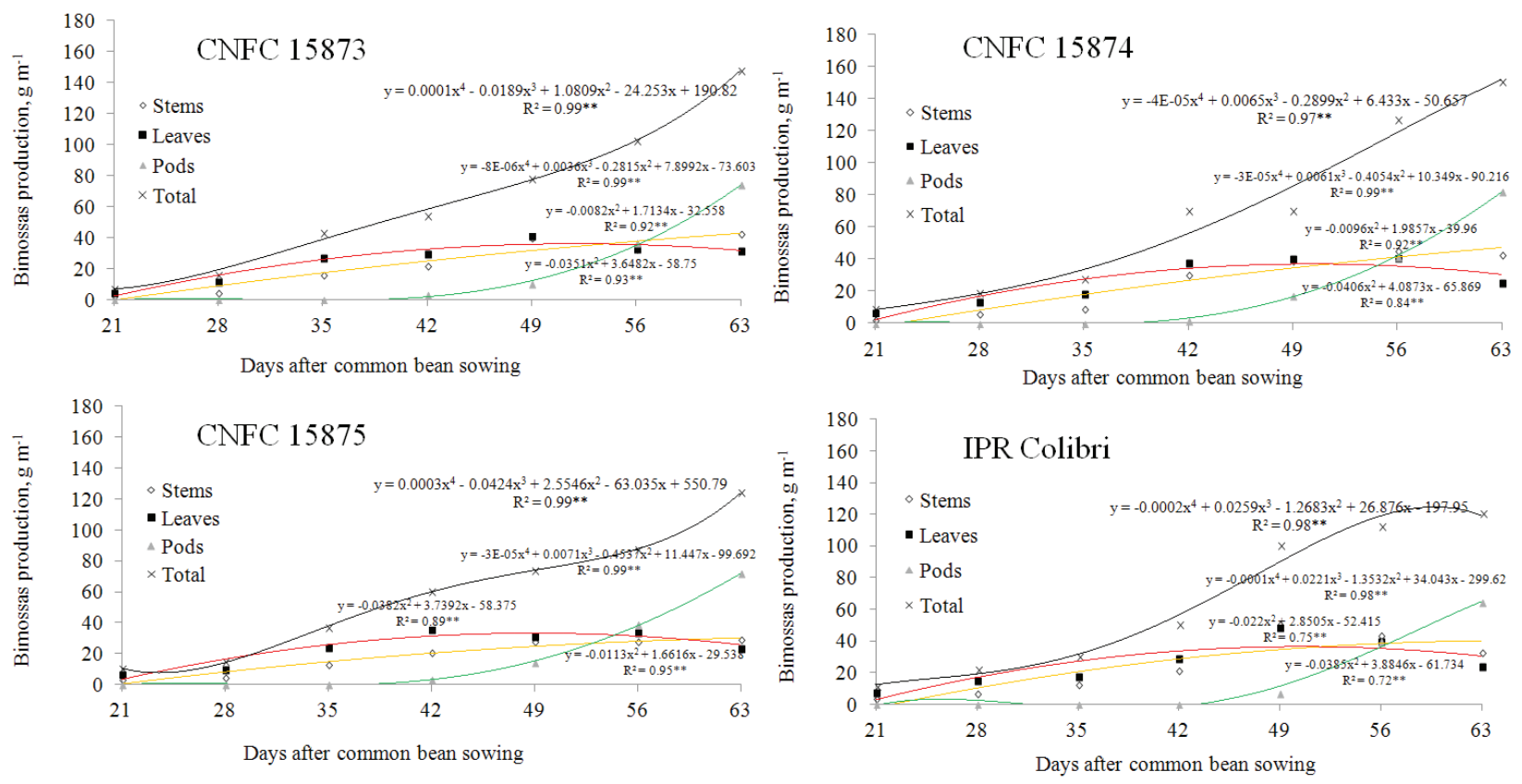

Figure 2. Biomass production of super early genotypes of common bean, during the 2015 growing season.
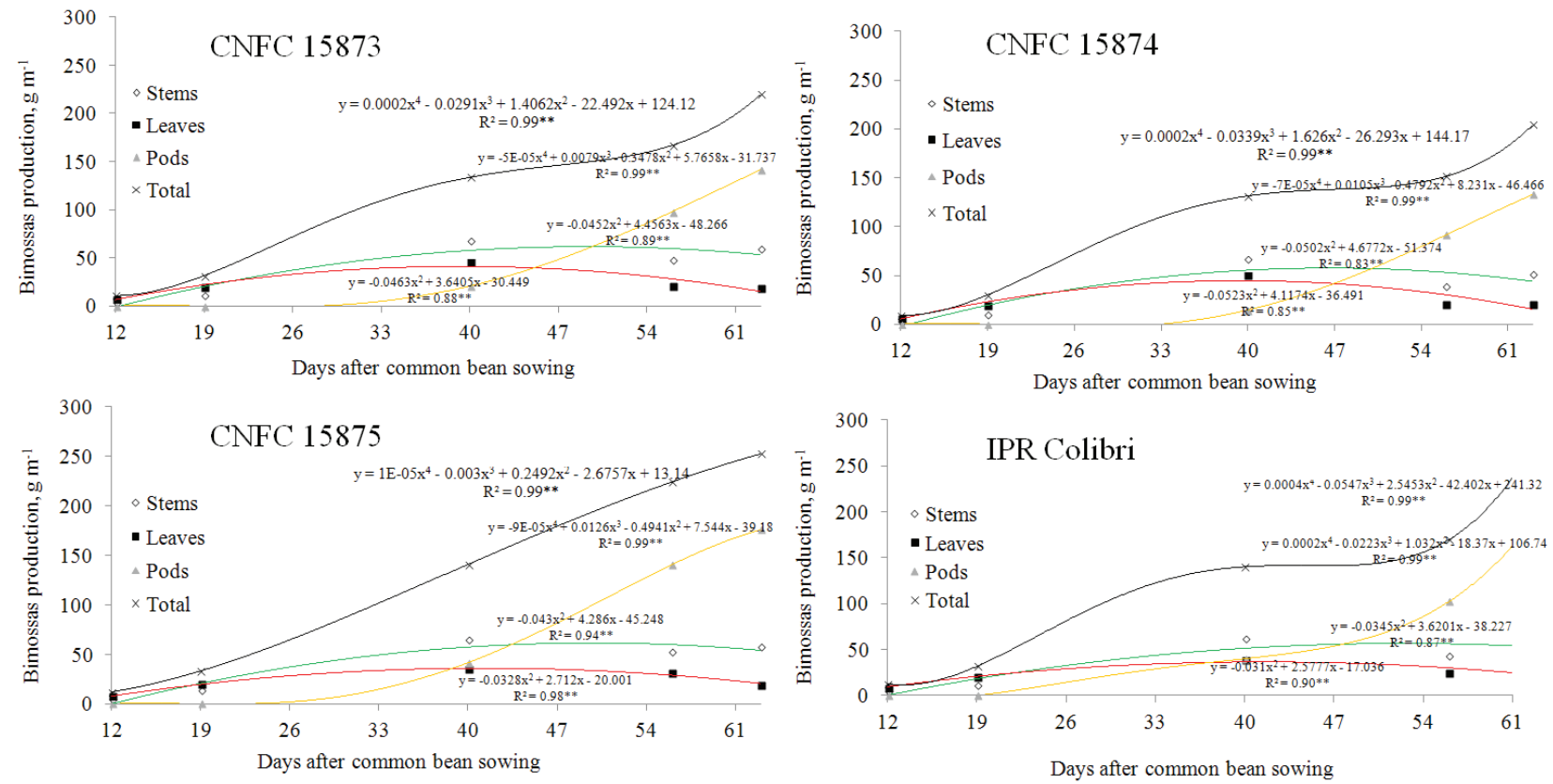

Figure 3. Biomass production of super early genotypes of common bean, during the 2015/2016 growing season. 
worst soil conditions where the experiment was conducted in the 2015 growing season, where the soil layer below $5 \mathrm{~cm}$ was nutritionally poor, with presence of toxic $\mathrm{Al}$ and low $\mathrm{Ca}$ and $\mathrm{Mg}$ contents (Table 1) (Sousa \& Lobato 2004, Fageria et al. 2011). This poor condition affects the photosynthesis and translocation of carbohydrates.
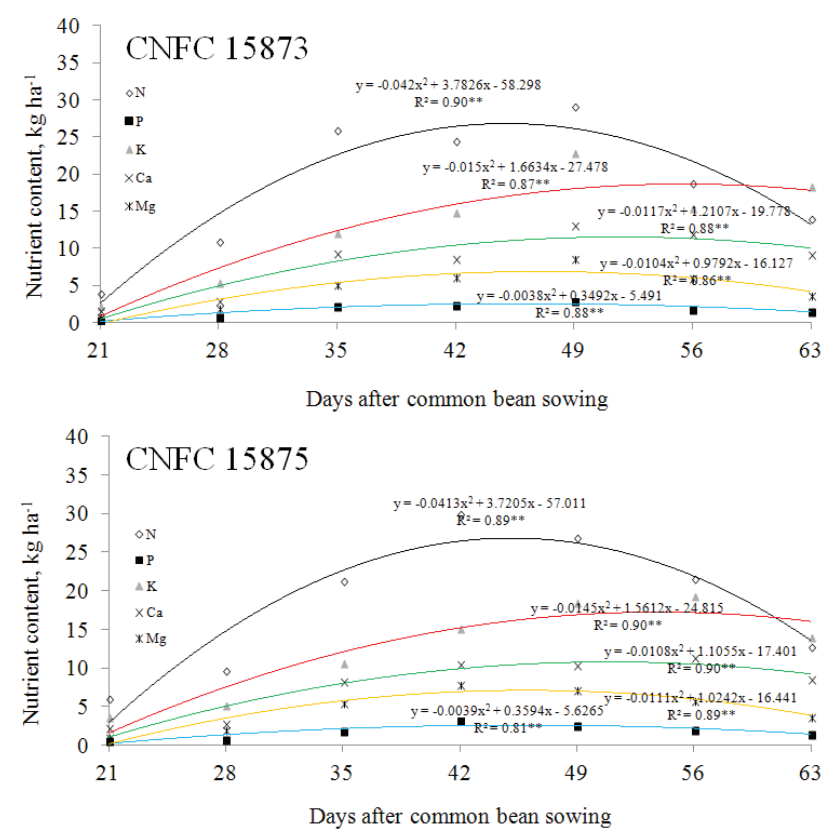

In the 2015 growing season, a greater number of pods per plant was observed in the CNFC 15874 genotype, which differed from the CNFC 15875 genotype (Table 2). The number of grains per pod was higher in the IPR Colibri cultivar, which differed from the CNFC 15875 genotype. The grain mass was higher in the CNFC 15874, CNFC 15875 and
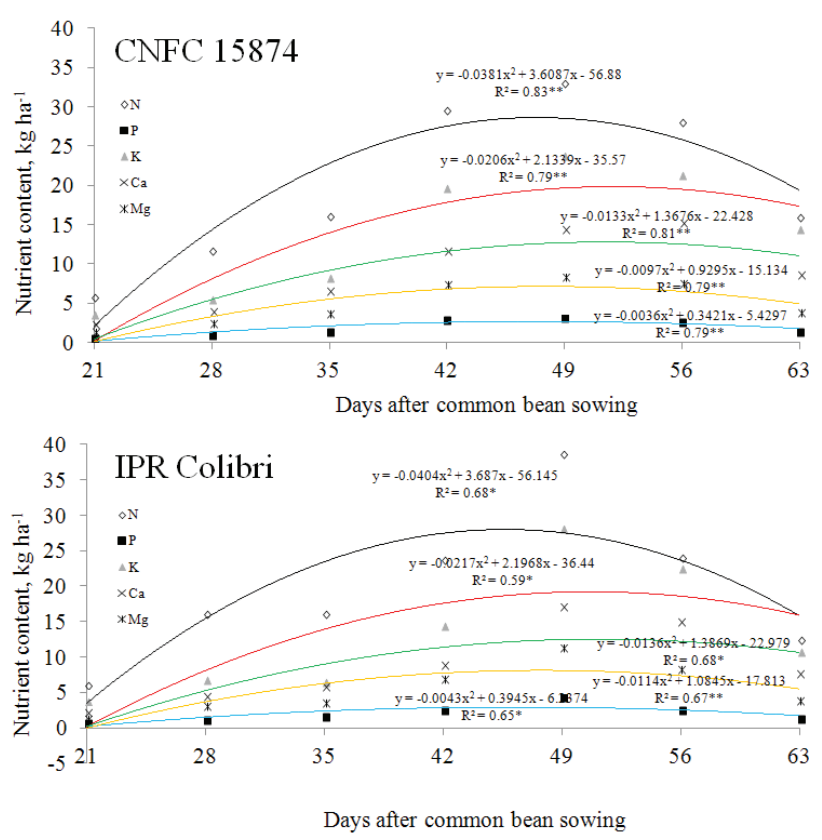

Figure 4. Accumulation of N, P, K, Ca and Mg in leaves of super early genotypes of common bean, during the 2015 growing season.
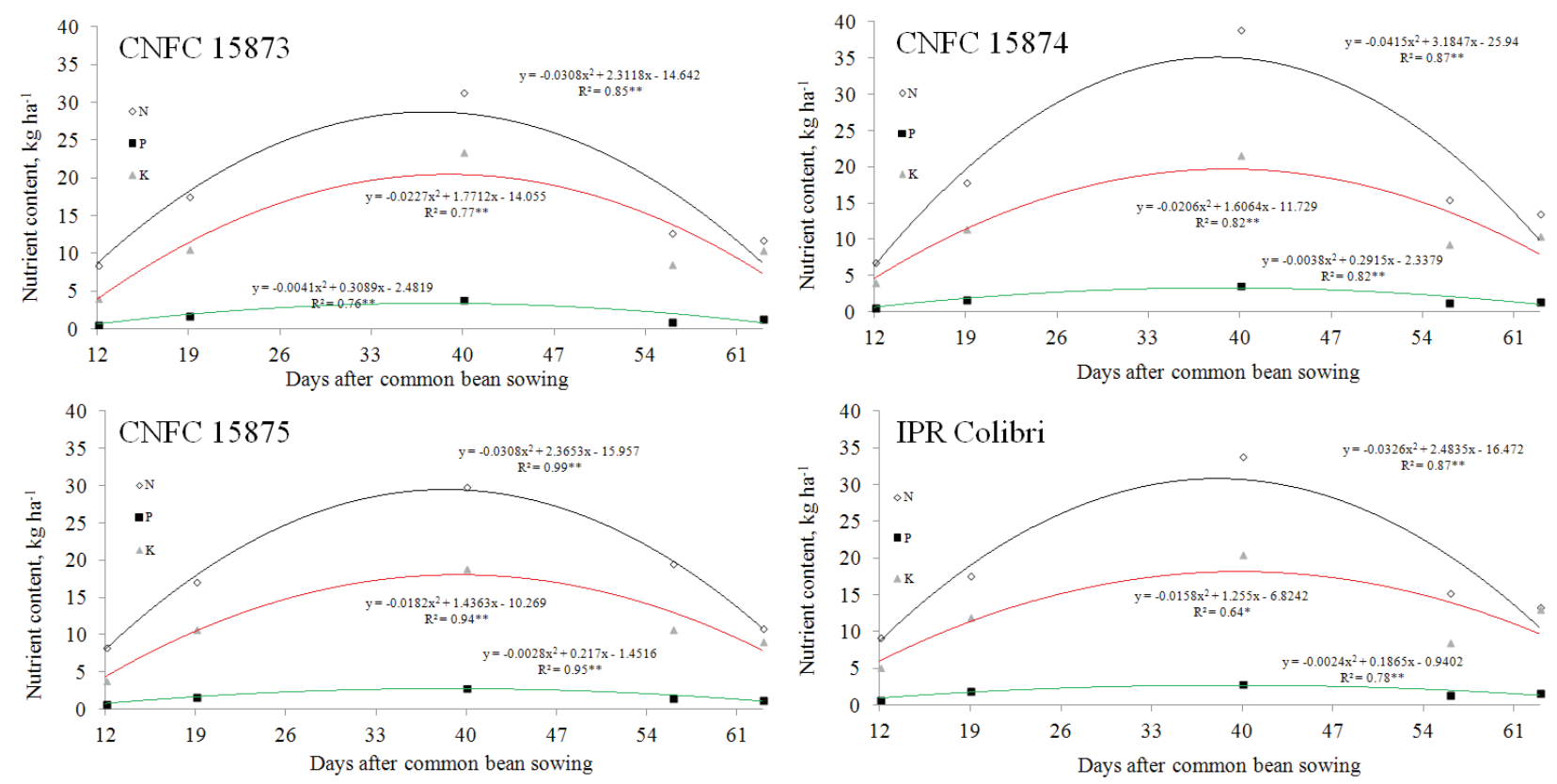

Figure 5. Accumulation of N, P and K in leaves of super early genotypes of common bean, during the 2015/2016 growing season. 
IPR Colibri genotypes, which differed from the CNFC 15873 genotype.

In the 2015/2016 growing season, the number of pods per plant and number of grains per pod were similar among the genotypes tested. The mass of 100 grains was higher in the CNFC 15875 cultivar, which was similar to the IPR Colibri cultivar and differed from the CNFC 15873 and 15874 CNFC genotypes. These differences in the yield components also provided differences in grain yield. The common bean grain yield is a function of its yield components: number of pods per plant, number of seeds per pod and mass of 100 grains (Araújo et al. 1996). The results obtained for number of pods

Table 2. Number of pods per plant (NPP), number of grains per pod (NGP), mass of 100 grains (MASS) and grain yield (YIELD) of super early genotypes of common bean.

\begin{tabular}{|c|c|c|c|c|}
\hline \multirow{3}{*}{ Genotype } & \multicolumn{4}{|c|}{2015 growing season } \\
\hline & NPP & NGP & MASS & YIELD \\
\hline & \multicolumn{2}{|c|}{ Number -} & $\mathrm{g}$ & $\mathrm{kg} \mathrm{ha}^{-1}$ \\
\hline$\overline{\text { IPR Colibri }}$ & $11.88 \mathrm{ab}^{*}$ & $4.73 \mathrm{a}$ & $22.58 \mathrm{a}$ & $2,365 \mathrm{a}$ \\
\hline CNFC 15873 & $13.25 \mathrm{ab}$ & $4.42 \mathrm{ab}$ & $18.03 \mathrm{~b}$ & $1,931 \mathrm{bc}$ \\
\hline CNFC 15874 & $13.78 \mathrm{a}$ & $4.46 \mathrm{ab}$ & $22.59 \mathrm{a}$ & $2,271 \mathrm{ab}$ \\
\hline CNFC 15875 & $9.43 \mathrm{~b}$ & $3.91 \mathrm{~b}$ & $22.65 \mathrm{a}$ & $1,805 \mathrm{c}$ \\
\hline Factor & \multicolumn{4}{|c|}{ Anova (F probability) } \\
\hline Genotype & 0.1381 & 0.1353 & 0.0074 & 0.0301 \\
\hline \multirow{3}{*}{ Genotype } & \multicolumn{4}{|c|}{ Growing season 2015/2016 } \\
\hline & NPP & NGP & MASS & YIELD \\
\hline & \multicolumn{2}{|c|}{ Number- } & $\mathrm{g}$ & $\mathrm{kg} \mathrm{ha}^{-1}$ \\
\hline IPR Colibri & $14.75 \mathrm{a}$ & $4.50 \mathrm{a}$ & $22.09 \mathrm{ab}$ & $3,011 \mathrm{a}$ \\
\hline CNFC 15873 & $14.25 \mathrm{a}$ & $5.00 \mathrm{a}$ & $19.72 b$ & $2,537 \mathrm{a}$ \\
\hline CNFC 15874 & $13.00 \mathrm{a}$ & $5.25 \mathrm{a}$ & $15.17 \mathrm{c}$ & $1,508 \mathrm{~b}$ \\
\hline CNFC 15875 & $15.25 \mathrm{a}$ & $4.50 \mathrm{a}$ & $23.51 \mathrm{a}$ & $2,530 \mathrm{a}$ \\
\hline Factor & \multicolumn{4}{|c|}{ Anova (F probability) } \\
\hline Genotype & 0.8585 & 0.1883 & 0.0031 & 0.0039 \\
\hline
\end{tabular}

per plant and number of grains per pod may explain the lower grain yield of the CNFC 15875 cultivar. On the other hand, the highest values obtained in all yield components for the CNFC 15874 genotype and the IPR Colibri cultivar explain their higher grain yield values.

In the 2015 growing season, despite the fact that the CNFC 15873 and CNFC 15874 genotypes had the highest total dry biomass production values, it was the IPR Colibri cultivar that had the highest grain yield. However, the IPR Colibri yield did not differ from the CNFC 15874 genotype. This result may be a reflection of the higher nutrient absorption capacity of the IPR Colibri, which had the highest values for all the evaluated nutrients, especially for $\mathrm{P}$ and N (Figure 4). Corroborating this hypothesis, there was a positive and significant correlation among the $\mathrm{N}$ and $\mathrm{P}$ accumulation in the common bean leaves with number of grains per pod, mass of 100 grains and grain yield (Table 3 ).

According to Fageria et al. (2011) and Viana et al. (2011), $\mathrm{N}$ and $\mathrm{P}$ are the nutrients that promote more response to grain yield increase in common bean. Moreover, the CNFC 15873 and CNFC 15875 genotypes accumulated nutrients faster than the others. This is typical of earlier plants, which require faster absorption of nutrients in a short period. However, this feature may damage the accumulation of nutrients, if there is some stress, and, consequently, the redistribution of nutrients to the reproductive structures. Plants that accumulate nutrients more slowly, such as the IPR Colibri, may have time to compensate this stress.

According to Fageria et al. (2011), plants with greater absorption capacity of nutrients tend to be more productive. The CNFC 15874 genotype had a higher production of dry biomass, increased

Table 3. Pearson's correlation among the N, P, K, Ca and Mg accumulation by leaves, with number of pods per plant (NPP), number of grains per pod (NGP), mass of 100 grains (MASS) and grain yield (YIELD) of super early genotypes of common bean.

\begin{tabular}{|c|c|c|c|c|c|c|c|c|c|}
\hline & $\mathrm{N}$ & $\mathrm{P}$ & $\mathrm{K}$ & $\mathrm{Ca}$ & $\mathrm{Mg}$ & NPP & NGP & MASS & YIELD \\
\hline $\mathrm{N}$ & - & $0.62 * *$ & $0.45^{*}$ & $-0.08^{\mathrm{ns}}$ & $0.22^{\mathrm{ns}}$ & $0.19^{\text {ns }}$ & $0.44^{*}$ & $0.81 * *$ & $0.57 * *$ \\
\hline $\mathrm{P}$ & - & - & $0.55^{*}$ & $-0.15^{\mathrm{ns}}$ & $0.17^{\mathrm{ns}}$ & $0.30^{\mathrm{ns}}$ & $0.50 *$ & $0.53 *$ & $0.52 *$ \\
\hline $\mathrm{K}$ & - & - & - & $-0.64 * *$ & $-0.44^{\mathrm{ns}}$ & $0.09^{\text {ns }}$ & $0.26^{\mathrm{ns}}$ & $0.48^{*}$ & $0.35^{\mathrm{ns}}$ \\
\hline $\mathrm{Ca}$ & - & - & - & - & $0.88 * *$ & $-0.07^{\mathrm{ns}}$ & $-0.16^{\mathrm{ns}}$ & $-0.09^{\mathrm{ns}}$ & $-0.17^{\mathrm{ns}}$ \\
\hline $\mathrm{Mg}$ & - & - & - & - & - & $0.12^{\text {ns }}$ & $0.03^{\text {ns }}$ & $0.10^{\mathrm{ns}}$ & $0.05^{\mathrm{ns}}$ \\
\hline NPP & - & - & - & - & - & - & $0.64 * *$ & $0.12^{\mathrm{ns}}$ & $0.67 * *$ \\
\hline NGP & - & - & - & - & - & - & - & $0.25^{\mathrm{ns}}$ & $0.90 * *$ \\
\hline MASS & - & - & - & - & - & - & - & - & $0.49 *$ \\
\hline
\end{tabular}

*,** and ${ }^{\mathrm{ns}}$ : significant at $5 \%$ and $1 \%$ and non-significant, respectively, by the $\mathrm{F}$ test. 
absorption of nutrients (with lower values only when compared to the IPR Colibri) and grain yield similar to the IPR Colibri. The CNFC 15875 genotype had a low production of dry biomass, less absorption of nutrients and, consequently, lower grain yield, among the genotypes.

In the 2015/2016 growing season, the IPR Colibri, CNFC 15875 and CNFC 15873 genotypes had the highest biomass production, and these results may be related to the higher grain yield of these genetic materials. On the other hand, the CNFC 15874 genotype had the lowest total biomass production, as well as a lower grain yield, and the highest accumulation of the nutrients $\mathrm{N}, \mathrm{P}$ and $\mathrm{K}$ in the leaves and a high yield potential, as shown in the previous growing season. However, the experimental area was infested with the Meloidogyne javanica nematode, to which this genotype seems to have a great sensitivity, what compromised its grain yield. Thus, even with number of pods per plant and number of grains per pod similar to the other genotypes, the CNFC 15874 had considerably reduced mass of 100 grains and, consequently, lower grain yield.

According to Juliatti et al. (2010), common bean is considered a susceptible host of Meloidogyne javanica, which can cause a 50-90\% reduction in grain yield. Ferraz (1985) suggested that the best way to solve the problem is to use resistant cultivars, since it provides no increase in production costs. Thus, as the other genotypes (IPR Colibri, CNFC 15873 and CNFC 15875) had similar grain yields, which were not statistically different, it is possible to infer that these genotypes are more resistant to the attack of Meloidogyne javanica.

Thus, the super early genotypes of common bean did not have different values for yield components and grain yield from the cultivar used as a control (IPR Colibri). In the winter growing season, the CNFC 15874 genotype had similar yield, when compared to the control, while the CNFC 15873 and CNFC 15875 genotypes produced similarly to the control, in the summer growing season (Table 2). Therefore, it seems that these super early genotypes are very promising for use both in the winter and summer growing seasons, by presenting competitive grain yield and lower crop cycle (63-70 DAE). This lower development cycle can provide conditions to cultivate two crops in the same area under rainfed conditions or three crops in irrigated areas.

\section{CONCLUSIONS}

1. During the early stage of plant development, the accumulation of biomass in stems and leaves occurs until flowering, when the biomass accumulation shifts to the pods;

2. Genotypes that absorb more nitrogen and phosphorus have higher grain yield;

3 . The average growing season of super early genotypes was 70 days in 2015 and 63 days in 2015/2016;

4. The CNFC 15874 is the most productive genotype in the winter season, with grain yield similar to the IPR Colibri cultivar (control). However, in the summer growing season, it had the lowest yield, probably because of the susceptibility to the Meloidogyne javanica present in the area;

5. In the summer season, the CNFC 15873 and CNFC 15875 genotypes achieve grain yield similar to the IPR Colibri cultivar.

\section{ACKNOWLEDGMENTS}

The authors thank the Conselho Nacional de Desenvolvimento Científico e Tecnológico (CNPq), for the financial support (Process 471812/2013-7).

\section{REFERENCES}

ALVAREZ, R. C. F.; CRUSCIOL, C. A. C.; NASCENTE, A. S. Growth analysis and yield of traditional, intermediate and modern upland rice cultivars. Pesquisa Agropecuária Tropical, v. 42, n. 4, p. 397-406, 2012.

ANDRADE, C. A. B. et al. Yield, growth and common matter partition in two common bean cultivars. Acta Scientiarum Agronomy, v. 31, n. 4, p. 683-688, 2009.

ANGHINONI, I. Fertilidade do solo e seu manejo em sistema plantio direto. In: NOVAIS, R. F. et al. (Eds.). Fertilidade do solo. Viçosa: Sociedade Brasileira de Ciência do Solo, 2007. p. 873-928.

ANTONIAZZI, N.; DESCHAMPS, C. Growth analysis of two barley cultivars after elicitors and fungicides treatment. Ciência Rural, v. 36, n. 4, p. 1065-1071, 2006.

ARAÚJO, R. S. et al. Cultura do feijoeiro comum no Brasil. Piracicaba: Associação Brasileira para Pesquisa de Potassa e do Fosfato, 1996.

AUGOSTINHO, L. M. D. et al. Acúmulo de massa seca e marcha de absorção de nutrientes em mudas de goiabeira 'Pedro Sato'. Bragantia, v. 67, n. 3, p. 577-585, 2008. 
CLAESSEN, M. E. C. Manual de métodos de análise de solo. 2. ed. Rio de Janeiro: Embrapa Solos, 1997.

CRUSCIOL, C. A. C. et al. Upland rice growth and mineral nutrition as affected by cultivars and sulfur availability. Soil Science Society of America Journal, v. 77, n. 1, p. 328-335, 2013.

DOORENBOS, J.; PRUITT, W. O. Crop and water requirements. Roma: FAO, 1976.

FAGERIA, N. K.; BALIGAR, V. C.; JONES, C. A. Growth and mineral nutrition of field crops. 3. ed. Boca Raton: CRC Press, 2011.

FALQUETO, A. R. et al. Partição de assimilados em cultivares de arroz diferindo no potencial de produtividade de grãos. Bragantia, v. 68, n. 3, p. 453-461, 2009.

FERRAZ, S. Summary report on the current status, progress and needs for Meloidogyne research in Brazil (Region III). In: SASSER, J. N.; CARTER, C. C. Advanced treatise on Meloidogyne: biology and control. Raleigh: North Carolina State University, 1985. p. 351-352.

FOOD AND AGRICULTURE ORGANIZATION (FAO). Faostat. 2016. Available at: <www.faostat.fao.org>. Access on: April 29, 2016.

HAAG, H. P. et al. Absorção de nutrientes pela cultura do feijoeiro. Bragantia, v. 26, n. 1, p. 381-391, 1967.

JULIATTI, F. C. et al. Reação de acessos de feijoeiro a nematoides de galhas. Bioscience Journal, v. 26, n. 5, p. 763-769, 2010.

LIMA, E. R. et al. Effects of the size of sown seed on growth and yield of common bean cultivars of different seed sizes. Brazilian Journal of Plant Physiology, v. 17, n. 3, p. 273-281, 2005.

MALAVOLTA, E.; VITTI, G. C.; OLIVEIRA, S. A. Avaliação do estado nutricional das plantas: princípios e aplicações. 2. ed. Piracicaba: Potafos, 1997.
NASCENTE, A. S.; MELO, L. C. Characterization of early genotypes of common bean. Annual Report of the Bean Improvement Cooperative, v. 58, n. 1, p. 119-120, 2015.

NASCENTE, A. S.; MELO, L. C.; ROSA, P. H. Growth analysis of early genotypes of common beans. Annual Report of the Bean Improvement Cooperative, v. 51, n. 1, p. 249-250, 2016.

PAGANI, A.; MALLARINO, A. P. Soil pH and crop grain yield as affected by the source and rate of lime. Soil Science Society of America Journal, v. 76, n. 5, p. 1877-1886, 2012.

PERGORARO, R. F. et al. Partição de biomassa e absorção de nutrientes pelo feijoeiro comum. Revista Caatinga, v. 27, n. 3, p. 41-52, 2014.

ROSALES-SERNA, R. et al. Biomass distribution, maturity acceleration and yield in drought-stressed common bean cultivars. Field Crops Research, v. 85, n. 2-3, p. 203-211, 2004.

SANTOS, L. A. et al. Growth, physiological indices and yield of common bean cultivars under different levels of fertilization. Revista Ceres, v. 62, n. 1, p. 107-116, 2015.

SOUSA, D. M. G.; LOBATO, E. Cerrado: correção do solo e adubação. 2. ed. Planaltina: Embrapa Cerrados, 2004.

VIANA, T. O. Adubação do feijoeiro cultivado no norte de Minas Gerais com nitrogênio e fósforo. Revista Ceres, v. 58, n. 1, p. 115-120, 2011.

VIEIRA, N. M. B. et al. Accumulation of macronutrients by different common bean cultivars grown in different plant densities in no-tillage crop system. Annual Report of the Bean Improvement Cooperative, v. 52, n. 1, p. 132133, 2009.

WIEN, H. C.; ALTSCHULER, S. L.; WALLACE, D. H. 14C-assimilate distribution in Phaseolus vulgaris L. during the reproductive period. Journal of the American Society for Horticultural Science, v. 101, n. 5, p. 510-513, 1976. 